\title{
A Case Report of Azathioprine and Phenytoin Induced Hepatitis
}

\section{Sanghavi K, Someshwari M, Rajanandh MG* and Seenivasan P}

Department of Pharmacy Practice, Sri Ramachandra University, Porur, Chennai, India

*Corresponding author: Rajanandh MG, Department of Pharmacy Practice, Faculty of Pharmacy, Sri Ramachandra University, Porur, Chennai, India, Tel: 04143230123; E-mail: mgrpharm@gmail.com

Received date: April 26, 2017; Accepted date: July 27, 2017; Published date: August 04, 2017

Copyright: () 2017 Sanghavi K, et al. This is an open-access article distributed under the terms of the Creative Commons Attribution License, which permits unrestricted use, distribution, and reproduction in any medium, provided the original author and source are credited.

\section{Case Description}

A 22-year-old Indian female patient was admitted in female General Medicine ward with the chief complaints of increased abdominal pain, fever, fatigue and yellowish discoloration of skin and eyes (Figure 1).

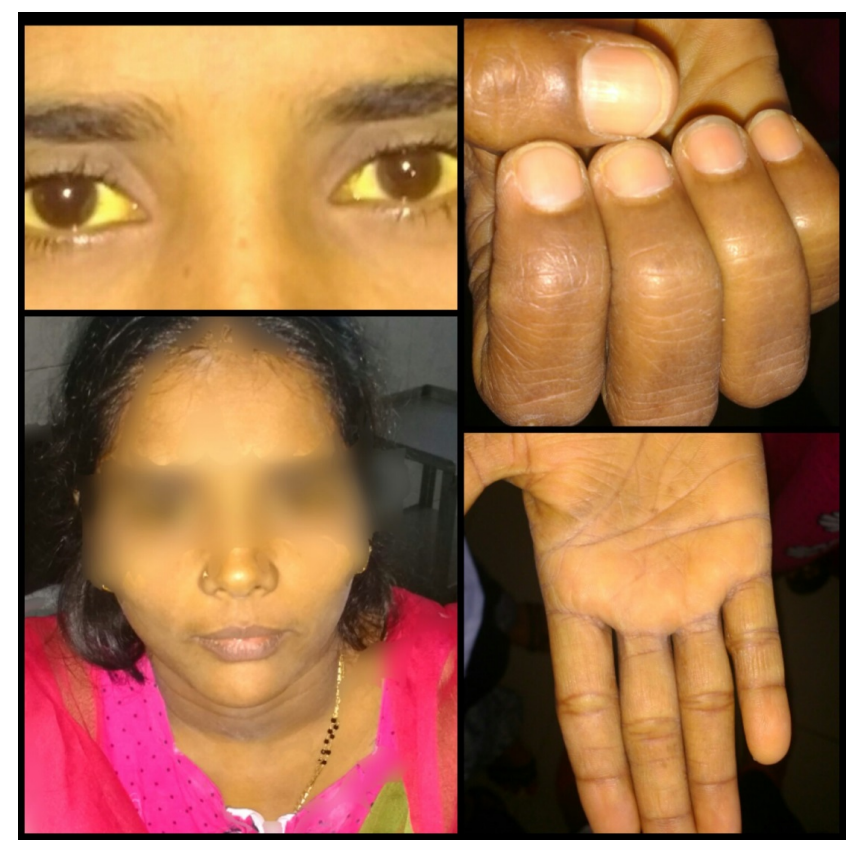

Figure 1: Yellowish discoloration of skin and eyes of a patient.

She was a known case of SLE and seizure and she was under treatment with azathioprine and phenytoin for past 5 months. During physical examination patient was conscious and co-operative. Lab investigations revealed elevated liver enzymes (Table 1).

\begin{tabular}{|l|l|l|l|}
\hline Liver Profile & Day 1 & Day 2 & Day 7 \\
\hline Bilirubin (0.1-1.2 mg/dl) & $2.43 \mathrm{mg} / \mathrm{dl}$ & $2.98 \mathrm{mg} / \mathrm{dl}$ & $6.8 \mathrm{mg} / \mathrm{dl}$ \\
\hline ALT (7-55 U/L) & $380 \mathrm{U} / \mathrm{L}$ & $424 \mathrm{U} / \mathrm{L}$ & $667 \mathrm{U} / \mathrm{L}$ \\
\hline AST (8-48 U/L) & $306 \mathrm{U} / \mathrm{L}$ & $439 \mathrm{U} / \mathrm{L}$ & $889 \mathrm{U} / \mathrm{L}$ \\
\hline
\end{tabular}

Table 1: Laboratory investigation reports of LFT.

Based on the above subjective and objective evidence, diagnosis was made as SLE, seizure with hepatitis. Patient was treated with Ranitidine $150 \mathrm{mg}$, Lamivudine $100 \mathrm{mg}$, Azathioprine $100 \mathrm{mg}$, Methotrexate $7.5 \mathrm{mg}$, Hydroxychloroquine $200 \mathrm{mg}$ and Phenytoin 50 mg. Patient was taking azathioprine and phenytoin for past 5 months. Based on clinical suspicion of azathioprine and phenytoin induced hepatitis, drug was withdrawn and treatment started with Cyclosporine $100 \mathrm{mg}$ and Chlorpromazine $50 \mathrm{mg}$ with Nitrazepam 5 $\mathrm{mg}$. A gradual reduction in symptoms and liver profile were observed.

Azathioprine is a immunosuppressive agent and it is a purine antimetabolite drug used in auto immune conditions like SLE and it acts by cleaving to 6 -mercaptopurine, which inhibits de novo purine synthesis and thereby which inhibits cell proliferation which impairs a lymphocyte functions. Phenytoin is an anti-epileptic drug; it works by slowing down impulses in the brain that cause seizures. However, prolonged use of these drugs may causes the adverse effects like hepatitis.

Hepatotoxicity due to azathioprine and phenytoin encompasses a spectrum of syndrome including hepatitis, hypersensitivity, cholestasis characterized by hepatocellular injury. Hepatic idiosyncratic drug reactions are believed to be due to either genetic polymorphism in drug metabolizing pathways or due to immunologic mechanisms. Both these mechanisms may be applicable in azathioprine and phenytoin induced hepatic injury. In the present case study, increased liver profile was observed on patient and increased symptoms of hepatits suggestive of azathioprine and phenytoin respectively, because the main adverse effects of azathioprine and phenytoin is hepatotoxicity.

Similar to this case report, most reported cases had acute hepatitis and all the cases had recovered upon drug withdrawal without any hepatic complications. The present case highlights a hepatic complication of azathioprine and phenytoin that had a wide range of latency, severity, duration and is probably reversible. Though methotrexate also having the chance of causing hepatotoxicity, in this case after withdrawal of methotrexate, no significant clinical changes was observed. Rechallenge was not performed as there are no guidelines on rechallenge in azathioprine and phenytoin related hepatitis. The toxicity was found to be severe and alternatives were available $[1,2]$.

The present case report suggests the possibility of developing hepatitis with azathioprine and phenytoin which was a possible ADR according to WHO-UMC system and Naranjo causality scale. Therefore until further data are available careful assessment required for patients receiving azathioprine and phenytoin and also more data is required to know the typical characteristics and risk factors associated with azathioprine and phenytoin induced hepatitis.

\section{References}

1. Anstey AV, Wakelin S, Reynolds NJ (2004) British association of dermatologists therapy. Guidelines and Audit Subcommittee. Guidelines for prescribing azathioprine in dermatology. Br J Dermatol 151: 1123-1132. 
Citation: Sanghavi K, Someshwari M, Rajanandh MG, Seenivasan P (2017) A Case Report of Azathioprine and Phenytoin Induced Hepatitis. J Pharmacovigil 5: 232. doi:10.4172/2329-6887.1000232

Page 2 of 2

2. Romagnuolo J, Sadowski DC, Lalor E, Jewell L, Thomson ABR (1998) Cholestatic hepatocellular injury with azathioprine: a case report and review of the mechanisms of hepatotoxicity. Can J Gastroenterol 12: 479-483. 